\title{
Evaluation of the ability of soil microorganisms and mycorrhizal fungi to promote rooting and development of Gnetum spp. cuttings
}

\author{
Laure Christine BILOA ${ }^{1}$, Alain BINDZI MBARGA ${ }^{2}$, Monique ANGUE ABOSSOLO ${ }^{3}$ and \\ Dieudonné NWAGA ${ }^{1^{*}}$
}

\author{
${ }^{1}$ Department of Microbiology, Faculty of Science, Soil Microbiology Laboratory, \\ Biotechnology Centre, University of Yaoundé I, P.O. Box 812 Yaoundé. \\ ${ }^{2}$ Department of Plant Biology, Faculty of Science, University of Yaoundé I, P.O. Box 812 Yaoundé. \\ ${ }^{3}$ Department of Soil Science, Faculty of Science, University of Yaoundé I, P.O. Box 812 Yaoundé. \\ *Corresponding author; E-mail: dnwaga@yahoo.fr; Tel: +237699931871/+237675563408
}

\begin{abstract}
Experiments were conducted to investigate the role of soil microorganisms from diverse Land Use Systems (LUS) on Gnetum rooting from Okola and Nkoteng sites (humid forest, Cameroon). Gnetummycorrhizal fungi symbiosis (Ecto and Arbuscular mycorrhizal fungi (EMF and AMF) is considered for the production of quality seedlings. The cuttings were planted using a factorial randomized design with sterilized and unsterilized substrates x LUS (mixed crop field: MCF, fallow: FA and secondary forest: SF); after sieving and autoclaving. The seedlings received AMF, AMF $+\mathrm{Sm}, \mathrm{Sm}$ (soil mixture) inoculum. The results indicate that soil sterilization reduce organic matter and phosphorus, plant growth and rooting; increase cutting mortality. The activity of CMA (infective propagules/g soil) is more important in MCF (12-35) than FA (0.41.4) and SF (0.16-0.40). This is confirmed by Scleroderma colonisation on Gnetum roots which is higher in MCF (54-66\%), medium in FA (34-54\%) and low in SF (15-33\%). Selected AMF inoculation increase Gnetum size (response: $60-67 \%$ un-sterilized, $71-85 \%$ sterilized substrate and $35-59 \%$ soil mixture) when compared to the non-inoculated control cuttings (20-30\%). Introducing AMF and EMF in the rooting medium may improve Gnetum cuttings quality. The work suggest that Gnetum can benefit from the double EMF and AMF symbiosis. (C) 2019 International Formulae Group. All rights reserved
\end{abstract}

Keywords: Mycorrhizal fungi, double symbiosis (arbuscular, ecto-mycorrhiza), Gnetum spp., Scleroderma sp.

\section{INTRODUCTION}

Gnetum plant originated from tropical rain forest of Congo basin, classified as the third non timber forest product. It is a vegetables of importance for food, medicine and income; for human diet as a good source of cellulose, proteins and minerals that are known for boosting the immune system and body development (Iqbal et al., 2009; Ahoudi et al., 2018). Thus Gnetum being among the most exploited and consumed natural non timber forest product in Central, West Africa and abroad. In Africa, there are four recognised species of Gnetum: $G$. buchholzianum Engl, G. africanum Welw, G. interruptum and G. latispicum distributed in tropical rain forests, which extend from Nigeria to Angola, through Cameroon and Democratic Republic of Congo (Biye et al., 2013). Gnetum seedlings production faces two major constraints: slow cuttings development in nurseries and slow growth of seedling in fields due to low soils fertility or nutrient availability. Thus, UNCED (1992) and CITES (2005) implemented the integrated and sustainable agricultural development and food 
security strategies at the sub-regional level. In most of the countries, soils in sub-Saharan Africa are ferralsol or acrisol, acidic, low in cation exchange capacity with a low fertility (FAO, 2003; Nwaga et al., 2010; Zeinabou et al., 2014). To achieve a good plant development and yield, an integrated soil fertility management is recommended for subSaharan African ecosystems taking into account the useful properties of beneficial microorganisms (Nwaga et al, 2000; Nwaga et al, 2010). Since mineral fertilizer cost is high and not environmentally friendly, a more ecofriendly approach is proposed actually. The interest of beneficial microorganisms applied in soils of sub-Saharan Africa for more than 20 years showed that the diversity of mycorrhizal fungi properties plays a major role in mineral and water availability for a sustainable production of seedlings and crops (Nwaga et al., 2010). In Burkina Faso, several species of Gnetum live in association with ectomycorrhizal fungi and the establishment of the symbiosis is very important for plant growth (Sanon et al., 2009a, 2009b). While in Cameroon, it is known that the roots of Gnetum africanum are colonized by ectomycorrhizal fungi (Onguene, 2000), Scleroderma sinnamariense according to Bechem (2011), Bechem and Alexander (2012 b). The main objective of this study is to have a better understanding of the role of soil beneficial microorganisms such as (arbuscular, ecto) mycorrhizal fungi and the effect of Land Use Systems (LUS) on the rooting capacity of Gnetum cuttings.

\section{MATERIALS AND METHODS Study site}

The soils were collected from two sites in Centre Region of Cameroon: Nkoteng at $4^{\circ}$ $42^{\prime}-4^{\circ} 60^{\prime} \mathrm{N}$ and $12^{\circ} 10^{\prime}-12^{\circ} 16^{\prime} \mathrm{E}$; and Okola at $4^{\circ} 13^{\prime}-4^{\circ} 48^{\prime} \mathrm{N}$ and $11^{\circ} 30^{\prime}-11^{\circ}$ $39^{\prime} \mathrm{E}$; these sites belongs to the agroecological zone of Guinean high savannah with a bimodal rainfall more pronounced dry season (Kamgaing, 2009). Site selection was guided by Gnetum abundance or scarcity in the area. The soils, in Centre Region of Cameroon are acrisols type rich in aluminium and iron oxide according to FAO classification (1976). These soils are acidic
( $\mathrm{pH}$ 4.0-5.5), clayey, poor low cation exchange capacity and organic matter.

\section{Soils of land use systems (LUS)}

In both sites, soils were sampled in three different LUS: forest, crop field (Hypomoea batatas (Convolvulaceae), Zea mays (Poaceae) and Musa paradisiaca (Musaceae) at Nkoteng; of Zea mays (Poaceae) with a few stalks of Inga edulis (Fabaceae) and Gnetum spp. and fallow (two years old) of Chromolaena odorata (Asteraceae) at Okola.

\section{Experimental 1 (spread on the propagator)}

Soils samples were collected in March during the small raining season. In each LUS, from a depth of $0-20 \mathrm{~cm}, 10$ replicates were made using standard method (Sieverding, 1991; Swift et al, 2001). An average sample consists in 40-50 kg of composite soil. Physical (sand, silt and clay) and chemical $(\mathrm{pH}$, organic matter, $\mathrm{C}, \mathrm{N}, \mathrm{P}$ and CEC) characterization of soils of different LUS were determined by the Soil Laboratory of IRAD Yaoundé according to standard methods. Soil are recovered from a crop field and coarse sand added in the proportions of soil/sand: 3/1. Soils were sieved to pass $2-4 \mathrm{~mm}$ sieve, then diluted with equal volume ratio with previously sieved coarse sand to lighten their texture and improve aeration. The diluted sample was then submitted to two types of treatments for the same volume; a portion was sterilized for 1 hour at $120^{\circ} \mathrm{C}$ by autoclaving and the other was unsterilized. The sterilized soil and the unsterilized soil were introduced into a cuttings propagator. The factorial $2 \times 3$ randomized 2 soils treatments (sterilized and unsterilized soils) $\times 3$ LUS (secondary forest, fallow and crop field) was applied for each of the 2 sites.

According to the method of Leakey (1990), the vines were defoliated and pruned to recommended dimensions of length of the internodes, with two half sheets with $50 \mathrm{~cm}^{2}$ of leaf area. The cuttings were planted in different compartments of the propagator containing a combination of 12 rooting substrates. During cultivation under the propagator, the leaves were moistened by very 
fine drops of water at least once a day using a sprayer.

Data on morphological parameters were collected weekly from the $2^{\text {nd }}$ week after planting until the end of the experiment ( 8 weeks) for the percentage of rooting, the death rate and the number of sheets. Data on the number, the size of the roots, and the size of seedlings are taken out of the propagator. A rooted cuttings is considered positive when it has at least one root of $1 \mathrm{~cm}$ of length. The rooted cuttings are removed from the propagator and introduced in the acclimatization cabinet.

Microbiological characterization of soil infectivity of the different LUS were determined by the Most Probable Number (MPN) of mycorrhizal fungi propagules according to Sieverding (1991). To do that, soils from various LUS were used with Sorghum bicolor (Poaceae) and Vigna unguiculata (Fabaceae) as host plants. For analysis of root colonization of Gnetum, two types of analysis were carried out: microscopic analysis (AMF anatomic structures) and visual analysis (EMF yellow colour).

\section{Experimental 2 (soil microorganisms and plantlets development)}

The forest soil is filled in polyethylene bags, $61 \mu$ thick, $15 \mathrm{~cm}$ wide and $19 \mathrm{~cm}$ high which perforation, $500 \mathrm{~g}$ of this mixture is introduced as a rooting substrate. Microbial material is a mixture of selected arbuscular mycorrhizal fungi (AMF) propagated on Sorghum bicolor (Poaceae) and Arachis hypogaea (Fabaceae) as host plants. Gigasporales (Gigaspora margarita, Scutellospora gregaria) and Glomerales (Glomus hoi, Glomus intraradices) is from the collection of Soil Microbiology Laboratory of the Biotechnology Centre, University of Yaoundé I. Each seedling receives 2 teaspoons $(10 \mathrm{~g})$ of an inoculum composed of selected AMF, soil mixture $(\mathrm{Sm})$, and mixture of $\mathrm{AMF}+\mathrm{Sm}$ following treatments, ectomycorrhizal control (Ec) treatment receives no inoculum; seedlings are thus put in an acclimatization cabinet for two months. The factorial randomized $2 \times 4$ to 2 provenances of plantlets (plantlets of sterilized and unsterilized soils) $\mathrm{x} 4$ types of treatments (ectomycorrhizal control, AMF, AMF + Sm, $\mathrm{Sm})$ for 2 sites with 16 seedlings per treatment. The data are evaluated after 2 months of implementation the test.

The AMF analysis is carried out 45 days after sowing, the fine roots are harvested and fragmented $(1-2 \mathrm{~cm})$ and then introduced into test tubes containing alcohol $\left(50^{\circ}\right)$ treated according to the staining method of Kormanik and McGraw (1982) to determine the Gnetum root colonization by the anatomic structures of AMF. The EMF analysis is determined by the presence or the absence of Scleroderma typical yellowing colour of colonized seedling Gnetum roots by EMF.

\section{Statistical analyses}

The data obtained were subjected to a two-way analysis of variance (ANOVA) followed by a Turkey's B-test at 5\% level. The data were analysed using SPSS Software Package 16.

\section{RESULTS \\ Soil influence of various LUS}

Activity of beneficial microorganisms of different LUS was assessed by MPN of AMF in both sites presented soil density of infectious propagules as low in forest soil (at least three times) and fallow soil and very high in the crop field soil. However, when Nkoteng soil is compared to Okola soil for the same LUS, the first showed three times higher in infective propagule density (Table 1).

The results of nodulation showed that Vigna unguiculata root nodules number was lower in secondary forest and higher in crop field and fallow (Table 1). On both sites, the number of nodules was slightly lower at Nkoteng than Okola soil, but this difference was not significant (Table 1). The size of the nodules, the smallest diameter was scored in forest and fallow soils. The nodules from the crop field soils had a diameter two times higher than in the forest soils. Since the experiment was not conducted on a confined environment, the sterilization reduced the number and the size of nodules regardless of the LUS of site used. It therefore causes mostly a reduction in the capacity of nitrogenfixing bacteria to improve on soil nitrogen. 


\section{Physico-chemical characterization of soils of various LUS}

Soil field capacity increases from forest to crop field through the fallow; the Nkoteng soil have a lower field capacity than Okola one. It was noticed that soil field capacity decreased after sterilization across the site or the LUS (Table 1). The $\mathrm{pH}\left(\mathrm{H}_{2} \mathrm{O}\right)$ of soils was acidic in the various LUS (4.5-4.9), and in all the soils, acidity increased with sterilization from 0.24 to 0.90 unit (5.40-5.12) and soil acidity is lower in the forest when compared to crop field or fallow (Table 2). Nkoteng soils is low in available phosphorus when compared to Okola one, and sterilization by autoclaving soil at $120{ }^{\circ} \mathrm{C}$ strongly reduce soil phosphorus availability. Sand content was very high; the various soils of LUS were sandy clayey with the exception of forest one at Nkoteng and Okola crop field which were clayey to sandy clay and clay very sandy respectively. The soil texture was not modified by sterilisation (Table 2).

\section{Effect of various LUS on rooting and mycorrhiza symbiosis of Gnetum}

In rooting seedlings of Gnetum in Nkoteng soils, there was no difference between the numbers of rooted seedlings throughout the experimental phase. The rooting began in the various treatments after the $4^{\text {th }}$ week after growing in the propagator (Figure 1a). The lowest settlement was recorded in the forest soils in relation to the crop field and fallow. In sterilized soils, the plantlets showed the lowest rooting rate than those from unsterilized soils. In Okola soils, the evolution of the plant growth in various substrates was very high compared to Nkoteng soils (Figure 1b). Forest soils, always had the weakest rooting development; the crop field and fallow had the same rooting rate from $2^{\text {nd }}$ to $6^{\text {th }}$ week. The seedlings from the sterilized soils, still recorded the lowest rate of rooting (Figure 1b).

Roots size of Gnetum in Nkoteng soils during the experimental phase from fallow soil have the longest roots compared to the crop field and forest for unsterilized soils. The roots of plantlets sown in unsterilized soils were longer and have a rapid growth compared to the one on sterilized soils. At the $4^{\text {th }}$ week, the average root growth was zero in sterilized soil. (Figure 2a). In Okola soil, unsterilized crop field and fallow soils growing records the longest roots; but unsterilized forest soil has the smallest roots (Figure 2b). The plantlets of sterilized soils have a rooting zero rate until the $4^{\text {th }}$ week and are shorter than those of unsterilized soil. When comparing root systems of seedlings from sterilized and unsterilized soils, those from unsterilized soils have a fibrous root system; one can specifically note the visible presence of ectomycorrhizal fungus Scleroderma that colours the root tips from unsterilized soil in bright yellow (Figure 3). Thus, the plantlets of Nkoteng soils have a highly developed root system, but with little root hairs over those of Okola soils. In terms of plantlets sterilized soil, they have a pivotal and slightly developed root system. The roots number of Gnetum in Nkoteng soil, from the $4^{\text {th }}$ week in unsterilized soils treatments showed that the forest soil has the smallest number of roots compared to the crop field and fallow soils with a gap of at least 2 roots per treatment (Figure 4a). As for plantlets sterilized soil, they still have a very low average number roots compared to seedling unsterilized soil. In Okola soils, the number of roots is low in the different LUS over Nkoteng soils with a mean difference of 2 roots at 8 weeks. The unsterilized crop field soil has the largest number of roots when compared with the forest and fallow soils (Figure 4b). This is shown by the curves representing roots number of the sterilized soil which are still below those representing unsterilized soil.

The mortality of Gnetum cutting decreases over time in LUS of Nkoteng soil (Figure 5a). Generally, the mortality rate is low in cuttings planted on unsterilized crop field, fallow and forest soils when compared to the one in all sterilized soils treatments which is very high. In Okola soils, mortality cutting is lower compared to Nkoteng soils. Height weeks after sowing, for unsterilized soils, crop field recorded the lowest mortality rates when compared to forest and fallow soils (Figure 5b). For sterilized soils, the mortality 
of cuttings is high whatever the LUS considered.

Root colonization of Gnetum by Scleroderma is very important in the LUS of Okola soils when compared to the one at Nkoteng soils. In unsterilized soils, ectomycorrhizal fungi abundance decrease from the crop field (66\%) to the fallow (54\%) and the forest soils (33\%) of Okola (Table 1). We have not observed Scleroderma colonization in plantlets of sterilized soils.

\section{Influence of beneficial microorganisms on rehabilitation Gnetum seedlings}

The root colonization (RC) of Gnetum by selected AMF differs significantly depending on the type of soil treatment (Table 2). Control and soil mixture (Sm) treatments which have not been inoculated with selected AMF show very low RC. The RC is very high in the AMF treatments for seedlings from sterilized soils $(60-70 \%)$ and lower on unsterilized soils (40-60\%), reduced when AMF is combined with sterilized soil mixture $(50-60 \%)$ or unsterilized $(40 \%)$ in both sites. In terms of seedlings from sterilized soils, they have a very high RC compared to those from unsterilized soils (Table 3). The presence of typical mycorrhizal propagules such as hyphae, vesicles, spores and much more arbuscules will definitely confirm the status of AMF colonization on Gnetum roots. This is very useful for the management and domestication of this plant.

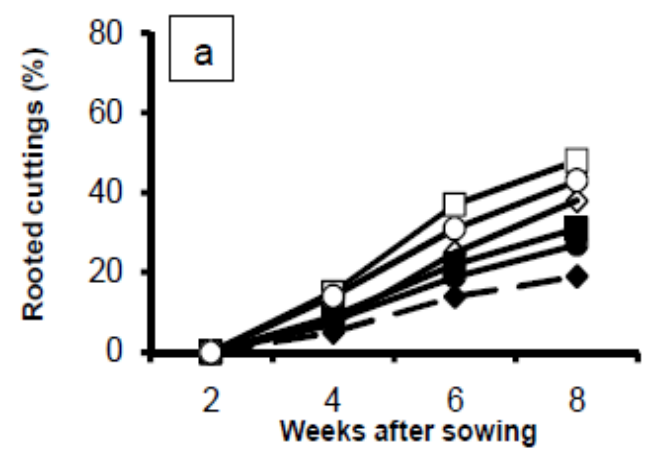

\section{Functioning of microbial consortia and Gnetum seedlings growth}

The increase in plant height is more obvious in mycorrhizal plants. After acclimatization, there is a significant difference between the different microbial treatments. The plants from Okola LUS are larger than those from Nkoteng LUS. Plants receiving treatment for a standard mixture of selected AMF and AMF + Sm have the best performances: although the effect of the soil mixture $(\mathrm{Sm})$ is not beneficial here. These results highlight the importance of evaluating the synergistic effect of the double mycorrhiza symbiosis (AMF and EMF) on the growth of Gnetum seedlings. Mycorrhizal response of seedling growth after inoculation using diverse microbial consortia treatments is observed in table 4 . The best response is observed using selected AMF inoculation on sterilised soil (71-85\%) compared to unsterilised one (60-67\%) from both Nkoteng and Okola soils. Soil mixture combined with selected AMF reduced the performances of AMF alone from both sites. While soil mixture $(\mathrm{Sm})(35-59 \%)$ alone is better than control (Ec) treatment (20-30\%) from all the sites. These results highlight the importance of the diversity of the functioning of soil microbial community for Gnetum seedling growth and development (Table 4).

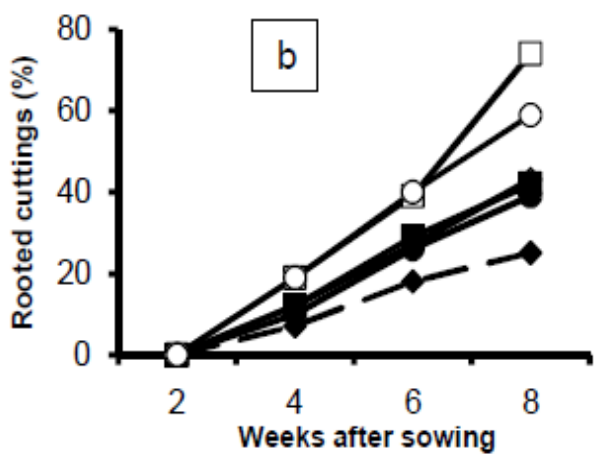

Figure 1: Evolution of the seedlings rooting of Gnetum spp .: a) Nkoteng; b) Okola:

C CIUs: crop field unsterilized soil; $\quad$ CfSs: crop field sterilized soil;

FaSs: fallow sterilized soil; $\diamond$ SfUs: secondary forest unsterilized soil;

O FaUs: fallow unsterilized soil;

SfSs: secondary forest sterilized soil; 

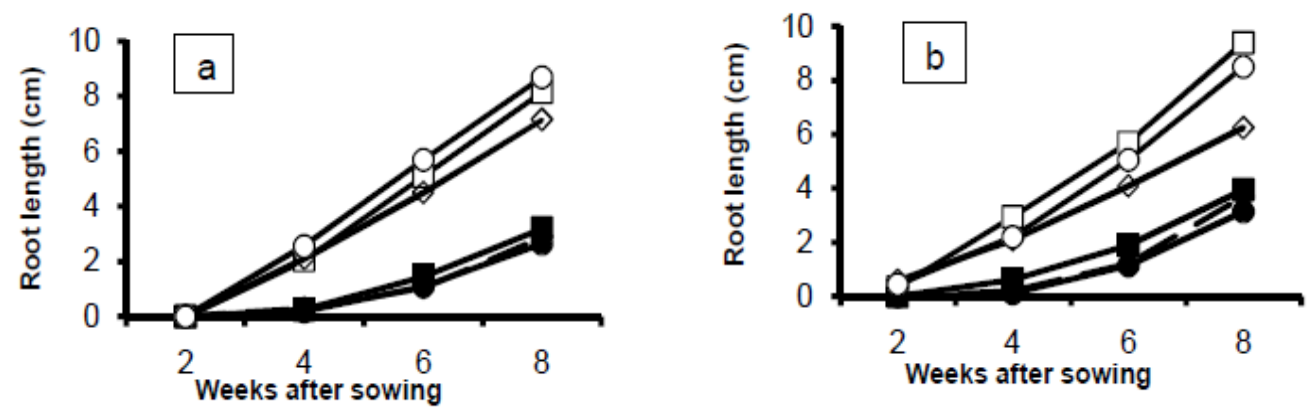

Figure 2: Evolution of Gnetum root size a) Nkoteng; b) Okola

C CfUs: crop field unsterilized; $\quad$ CeSs: crop field sterilized soil; O FaUs: fallow unsterilized soil;

- FaSs: fallow sterilized soil; $\Delta$ SfUs: secondary forest unsterilized soil; $\quad \Delta$ SfSs: secondary forest sterilized soil;
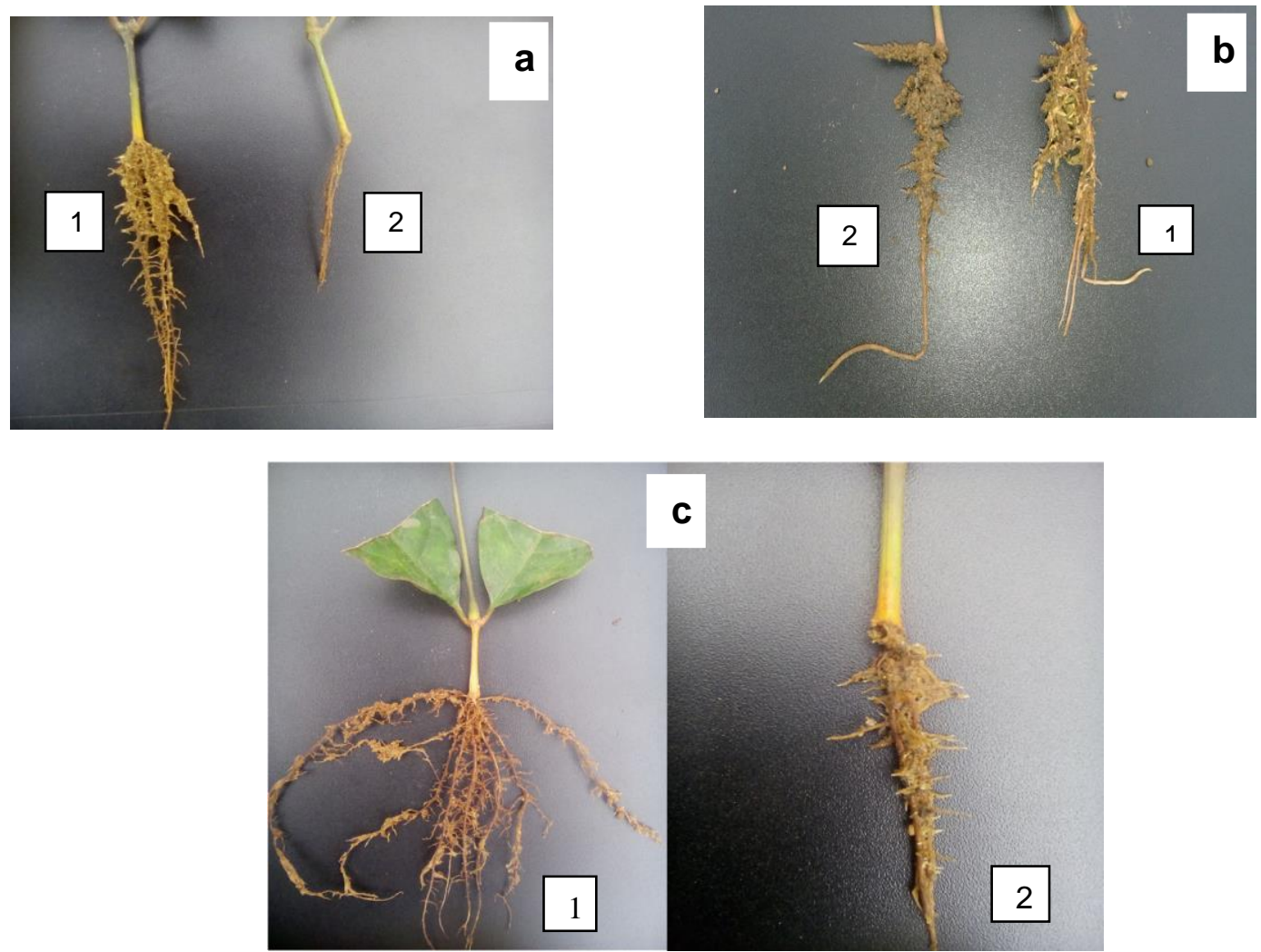

Figure 3: Mycorrhizal roots of Gnetum (Scleroderma in yellow colour) to the output (two months after sowing) the spread in propagator : a) Okola fallow; b) Okola crop field; c) Nkoteng mixed crop field; 1) unsterilized soil; 2) sterilized soil. 

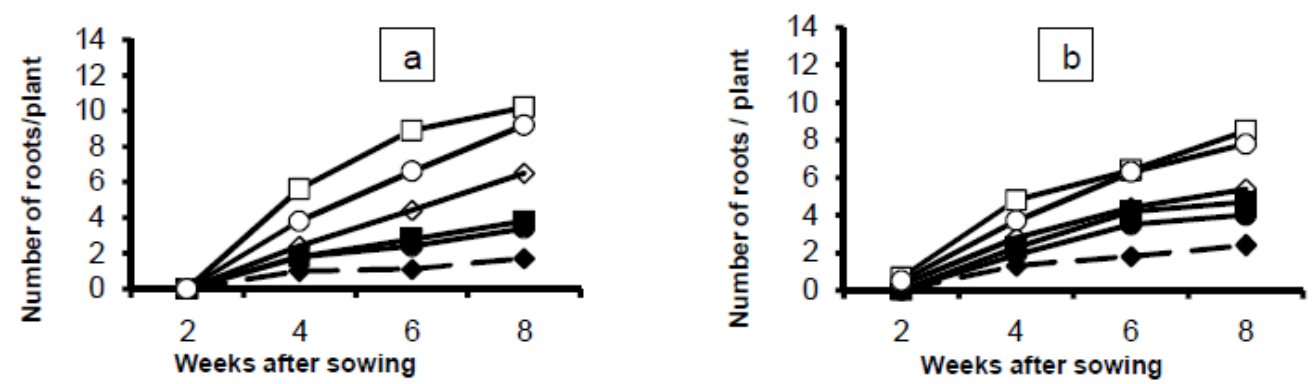

Figure 4: Evolution of Gnetum roots number a) Nkoteng; b) Okola: $\boldsymbol{\square}$ CfUs: crop field unsterilized soil; $\quad$ CfS: crop field sterilized soil; OFaUs: fallow unsterilized soil; secondary forest unsterilized soil; $\downarrow$ SfSs: secondary forest sterilized soil;

\footnotetext{
OFaSs: fallow soil sterilized; $\diamond$ SfUs:
}
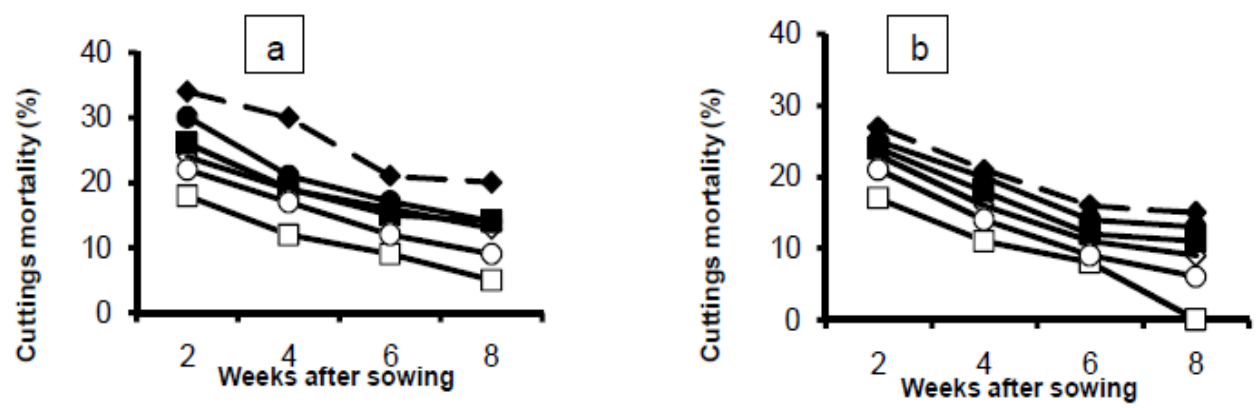

Figure 5: Evolution of cuttings mortality of Gnetum a) Nkoteng; b) Okola; $\quad$ C CfUs: crop field unsterilized soil; $E_{\text {CfS }}$ crop field sterilized soil; OFaUs: fallow unsterilized soil; OFaSs: fallow soil sterilized; $\diamond$ SfUs: secondary forest unsterilized soil; $\diamond$ SfSs: secondary forest sterilized soil;

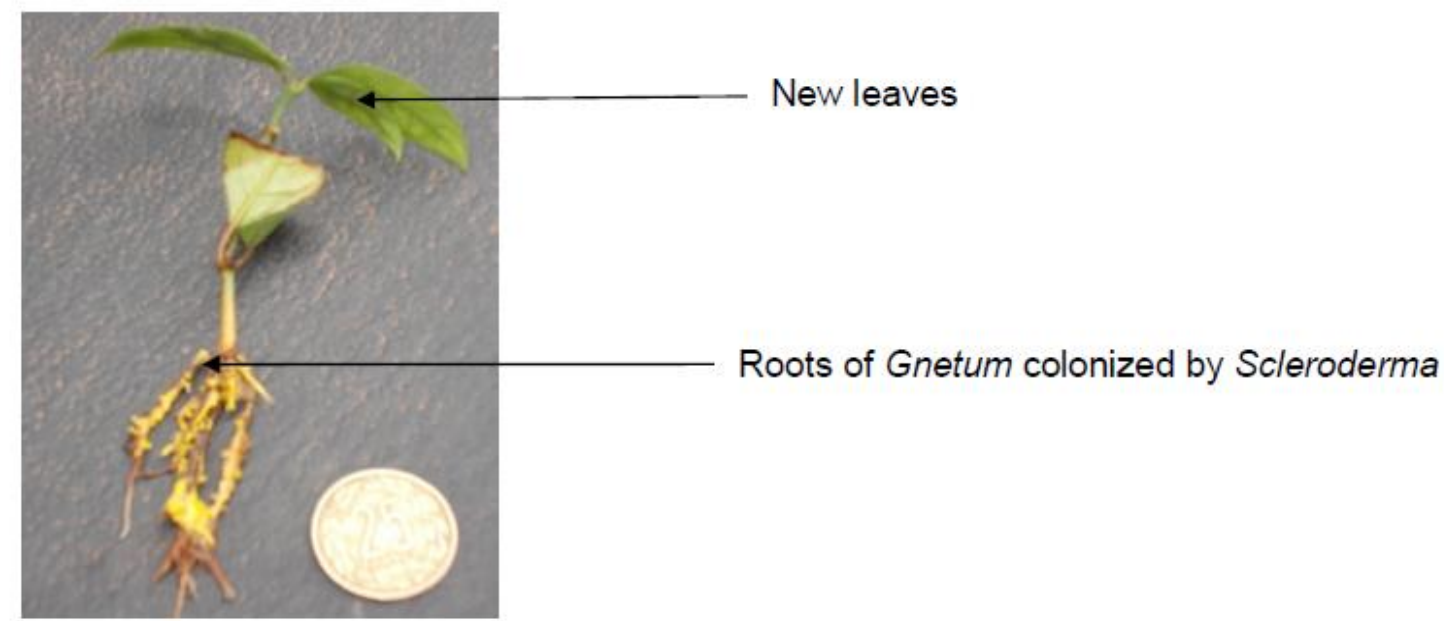

Figure 6: Ectomycorrhiza on a Gnetum plantlet two months after sowing on mixed field crop in unsterilized soil of Okola. 
Table 1: Activity of beneficial microorganisms of various LUS.

\begin{tabular}{|c|c|c|c|c|c|c|c|c|c|c|c|c|}
\hline \multirow{3}{*}{$\begin{array}{l}\text { Sites } \\
\text { Treatments } \\
\text { Parameters }\end{array}$} & \multicolumn{6}{|c|}{ Okola soil } & \multicolumn{6}{|c|}{ Nkoteng soil } \\
\hline & \multicolumn{2}{|c|}{$\mathrm{Cf}$} & \multicolumn{2}{|c|}{$\mathrm{Fa}$} & \multicolumn{2}{|c|}{ Sf } & \multicolumn{2}{|c|}{$\mathrm{Cf}$} & \multicolumn{2}{|c|}{$\mathrm{Fa}$} & \multicolumn{2}{|c|}{ Sf } \\
\hline & Us & Ss & Us & Ss & Us & Ss & Us & Ss & Us & Ss & Us & Ss \\
\hline $\begin{array}{c}\text { Number of } \\
\text { infectiues } \\
\text { propagules / } 100 \mathrm{~g} \\
\text { soil }\end{array}$ & \multicolumn{2}{|c|}{3528 a } & \multicolumn{2}{|c|}{$143 \mathrm{c}$} & \multicolumn{2}{|c|}{$39 \mathrm{~d}$} & \multicolumn{2}{|c|}{$1172 \mathrm{a}$} & \multicolumn{2}{|c|}{$43 \mathrm{~d}$} & \multicolumn{2}{|c|}{$16 \mathrm{e}$} \\
\hline $\begin{array}{l}\text { Nodules number } \\
\text { /seedling }\end{array}$ & $\begin{array}{l}14 \\
1,93 a\end{array}$ & $\begin{array}{l}9 \quad \pm \\
1,34 \mathrm{~b}\end{array}$ & $\begin{array}{l}13 \\
4,76 \mathrm{a}\end{array}$ & $\begin{array}{l}6 \pm \\
3,69 \mathrm{c}\end{array}$ & $\begin{array}{l}7 \pm 2,37 \\
\text { bc }\end{array}$ & $\begin{array}{l}4 \quad \pm \\
1,05 \mathrm{~d}\end{array}$ & $\begin{array}{l}11 \\
1,31 \mathrm{a}\end{array}$ & $\begin{array}{l}8 \pm \\
1,37 \mathrm{~b}\end{array}$ & $\begin{array}{l}10 \\
0,42 \mathrm{a}\end{array}$ & $\begin{array}{l}6 \pm \\
1,39 \mathrm{c}\end{array}$ & $\begin{array}{l}9 \pm 1,28 \\
\mathrm{ab}\end{array}$ & $2_{0,73 \mathrm{~d}}^{ \pm}$ \\
\hline $\begin{array}{l}\text { Nodules } \\
(\mathrm{mm})\end{array}$ & $\begin{array}{l}2,70= \\
0,25 \mathrm{a}\end{array}$ & $\begin{array}{l}1,65 \pm \\
0,24 \mathrm{c}\end{array}$ & $\begin{array}{l}1,95 \\
0,15 b\end{array}=$ & $\begin{array}{l}1,60 \pm \\
0,39 \\
\text { cd }\end{array}$ & $\begin{array}{l}1,90 \\
0,21 \mathrm{~b}\end{array}=$ & $\begin{array}{l}1,40 \pm \\
0,21 \\
\text { de }\end{array}$ & $\begin{array}{l}1,70 \\
0,25 \mathrm{a}\end{array}=$ & $\begin{array}{l}0,85 \pm \\
0,24 \mathrm{c}\end{array}$ & $\begin{array}{l}1,35 \\
0,24 b\end{array}=$ & $\begin{array}{l}1,20 \pm \\
0,34 \mathrm{~b}\end{array}$ & $\begin{array}{l}1,40 \\
0,21 \mathrm{~b}\end{array}=$ & $\begin{array}{l}0,85 \pm \\
0,24 c\end{array}$ \\
\hline $\begin{array}{l}\text { Field of soil used. } \\
(\%)\end{array}$ & 30 & 25 & 28 & 25 & 27 & 24 & 28 & 23 & 27 & 24 & 25 & 23 \\
\hline $\begin{array}{l}\text { Root colonization } \\
\text { of Gnetum by } \\
\text { Scleroderma }(\%)\end{array}$ & $66 \pm 5,1$ a & 0 & $54 \pm 5,1 \mathrm{a}$ & 0 & $33 \pm 4,8 \mathrm{~b}$ & 0 & $54 \pm 5,1$ a & 0 & $34 \pm 5,1 \mathrm{~b}$ & 0 & $15 \pm 5,2 \mathrm{c}$ & 0 \\
\hline
\end{tabular}

Fa: fallow; Cf: crop field; Sf: Secondary forest; Ss: Sterilized soil; Us: Unsterilized soil;

The figures bearing the same letter in the same column are not significantly different at $\mathrm{P}<5 \%$. 
Table 2: Physico-chemical composition of soils.

\begin{tabular}{|c|c|c|c|c|c|c|c|c|c|c|c|c|c|}
\hline \multirow{4}{*}{\multicolumn{2}{|c|}{$\begin{array}{l}\text { LUS of sites } \\
\text { Elements }\end{array}$}} & \multicolumn{12}{|c|}{ Soil samples } \\
\hline & & \multicolumn{6}{|c|}{ Nkoteng site } & \multicolumn{6}{|c|}{ Okola site } \\
\hline & & \multicolumn{2}{|c|}{$\mathrm{Cf}$} & \multicolumn{2}{|c|}{$\mathrm{Fa}$} & \multicolumn{2}{|c|}{ Sf } & \multicolumn{2}{|c|}{$\mathrm{Cf}$} & \multicolumn{2}{|c|}{$\mathrm{Fa}$} & \multicolumn{2}{|c|}{ Sf } \\
\hline & & Us & Ss & Us & Ss & Us & Ss & Us & Ss & Us & Ss & Us & Ss \\
\hline & Humidity (\%) & 2,00 & 2,40 & 2,20 & 2,20 & 2,00 & 2,00 & 1,60 & 2,02 & 1,40 & 2,22 & 15,5 & 1,4 \\
\hline \multirow{6}{*}{ 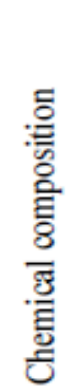 } & $\begin{array}{l}\text { Organic matter } \\
(\mathrm{g} / \mathrm{kg})\end{array}$ & 54,40 & 18,00 & 37,80 & 19,00 & 50,20 & 17,20 & 117,2 & 29,2 & 26,6 & 19,00 & 30,2 & 19,8 \\
\hline & C org. $(\mathrm{g} / \mathrm{kg})$ & 31,60 & 10,40 & 22,00 & 11,00 & 29,20 & 10,00 & 68,00 & 17,00 & 15,4 & 11,00 & 17,6 & 11,4 \\
\hline & $\mathrm{N}$ total $(\mathrm{g} / \mathrm{kg})$ & 2,00 & 1,80 & 1,80 & 1,80 & 2,20 & 1,40 & 1,60 & 2,20 & 3,40 & 3,40 & 2,20 & 1,60 \\
\hline & $\mathrm{C} / \mathrm{N}$ & 15,8 & 5,77 & 12,22 & 6,11 & 13,27 & 7,14 & 42,5 & 7,72 & 4,52 & 3,23 & 8,00 & 7,13 \\
\hline & $\begin{array}{l}\text { Available } \\
\text { phosphorus }\end{array}$ & 61,48 & 9,66 & 10,50 & 8,88 & 18,26 & 4,56 & 49,14 & 8,06 & 22,30 & 12,28 & 3,18 & 2,96 \\
\hline & $\begin{array}{l}(\mathrm{mg} / \mathrm{kg}) \text { Bray } 2 \\
\mathrm{pH}\left(\mathrm{H}_{2} \mathrm{O}\right)\end{array}$ & 4,88 & 5,35 & 4,50 & 5,25 & 4,88 & 5,40 & 4,83 & 5,12 & 4,68 & 5,18 & 4,82 & 5,05 \\
\hline \multicolumn{2}{|c|}{ Clay (\%) } & 39,5 & 26,5 & 36,8 & 37,0 & 39,1 & 33,38 & 33,0 & 33,0 & 43,3 & 31,6 & 42,6 & 31,5 \\
\hline \multicolumn{2}{|c|}{ Silt (\%) } & 7,5 & 8,20 & 4,24 & 6,50 & 5,90 & 6,10 & 7,5 & 9,76 & 8,96 & 9,14 & 9,1 & 4,60 \\
\hline \multicolumn{2}{|c|}{ Sand (\%) } & 53,00 & 65,30 & 58,96 & 56,50 & 55,00 & 60,52 & 59,50 & 57,24 & 47,74 & 59,26 & 48,30 & 63,90 \\
\hline
\end{tabular}

Fa: fallow; Cf: mixed crop field; Sf: Secondary forest; Us: unsterilized soil; Ss: sterilized soil. 
Table 3: Root colonization of AMF on Gnetum plants after acclimatization.

\begin{tabular}{lcccc}
\hline Soil plantlets origin & \multicolumn{2}{c}{ Nkoteng } & \multicolumn{2}{c}{ Okola } \\
\hline Treatments & Us (\%) & Ss (\%) & Us (\%) & Ss (\%) \\
\hline Ecto & $10 \mathrm{cde}$ & $20 \mathrm{~cd}$ & $20 \mathrm{~cd}$ & $30 \mathrm{c}$ \\
& & & & \\
\hline AMF & $40 \mathrm{bc}$ & $60 \mathrm{ab}$ & $60 \mathrm{ab}$ & $70 \mathrm{a}$ \\
\hline AMF + Soil mixture (Sm) & $40 \mathrm{bc}$ & $50 \mathrm{~b}$ & $40 \mathrm{bc}$ & $60 \mathrm{ab}$ \\
\hline Soil mixture (Sm) & & & & \\
& $20 \mathrm{~cd}$ & $30 \mathrm{c}$ & $30 \mathrm{c}$ & $40 \mathrm{bc}$ \\
\hline
\end{tabular}

The figures bearing the same letter in the same column are not significantly different at $\mathrm{P}<5 \%$.

Ecto: ectomycorrhizal control; AMF: arbuscular mycorrhizal fungi; $\mathrm{AMF}+\mathrm{Sm}$ : arbuscular mycorrhizal fungi + soil mixture; Sm: soil mixture; Us: unsterilized soil; Ss: sterilized soil;

Table 4: Mycorrhizal response (\% over the control) after acclimatization on Gnetum plants.

\begin{tabular}{lccccc}
\hline Origin of soil plantlets & \multicolumn{2}{c}{ Unsterilized soil } & Sterilized soil & \multirow{2}{*}{ Ranking } \\
\cline { 1 - 5 } Treatments & Nkoteng & Okola & Nkoteng & Okola & \\
\hline Ecto & 20 & 28 & 28 & 30 & 4 \\
\hline AMF & 60 & 67 & 71 & 85 & 1 \\
\hline AMF + Soil mixture (Sm) & 46 & 56 & 67 & 76 & 2 \\
\hline Soil mixture (Sm) & 35 & 40 & 43 & 59 & 3 \\
\hline $\begin{array}{l}\text { AMF: Arbuscular mycorrhizal fungi; Ec: control ectomycorrhizal (non inoculated); AMF + Sm: Arbuscular mycorrhizal } \\
\text { fungi + soil mixture; Sm: soil mixture; inoculum (mixed field crop, fallow and forest); Us: Unsterilized soil; Ss: Sterilized } \\
\text { soil. }\end{array}$
\end{tabular}

\section{DISCUSSION}

\section{Effect of sterilization on beneficial microorganisms and soil properties}

The autoclave sterilized soils are poor in nutrients. The activity of rhizobia, nitrogen fixing organisms is significantly reduced (50\% less number and size of nodules of Vigna unguiculata, Fabaceae) than those from unsterilized soils. The requirements of species related to rooting substrate are correlated to the state of water in the soil, and better results are achieved when media with good aeration and reduced water retention capacity are used
(İsfendiyaroğlu et al., 2009). Sterilization has significantly reduced residual soil water. Soil chemical properties such as organic matter and phosphorus were greatly reduced by the sterilization. Organic matter increase water soil retention capacity and its reduction will decrease soil water field capacity and also the activity of soil microorganisms. The soil-sand mixture of the growing medium may become deleterious after sterilization for the development of mycorrhizal fungi. 


\section{Physico-chemical properties and activity of beneficial soil microorganisms}

Whatever site or LUS considered, generally the crop field is the one recording the best physical and chemical soils properties and activity of soil beneficial microorganisms when compared to the fallow and the forest ecosystems. Thus, better activity of soil beneficial microorganisms may result in better symbiosis with plants. The activity of mycorrhizal fungi is related to their inoculum potential. Since the number of infective propagules is very high in the crop fields (Okola and Nkoteng sites) and very low in the fallow or forest sites, AMF is more active here in the agricultural ecosystem. These results are not in concordance with those of authors claiming that forest ecosystems possess a higher AM fungi activity in comparison to agricultural ecosystems (Ngonkeu et Nwaga, 1998; Nwaga et al., 2003); but for rhizobia, legumes nodulating bacteria are in concordance with other authors such as Ngo Nkot et al. (2011). The results of the Most Probable Number (MPN) of AM fungi (root infectivity) and nitrogen fixing bacteria (root nodulation) indicate a greater microbial activity on Okola when compared to Nkoteng soils. This important activity seems to be explained by the clay-sandy texture of various soils used and significant nutrient contents. The sandy clay textures are the best texture for the development of microorganisms such as symbiotic soil fungi and bacteria.

\section{Soil effect on seedling growth of Gnetum}

Gnetum rooting cuttings started from the $4^{\text {th }}$ week in soils of various LUS used, we noticed that the crop field soil provide the best results. The average rate of registered Gnetum rooting for the crop field soil from Okola, (74\%), which may be compared to the decomposed sawdust and sand substrate mixture (70\%) obtained by ICRAF (2012). This high rooting is higher than $27 \%$ obtained on Gnetum by Kutnjem (2008). These results indicate that Gnetum rooting may be improved by a better management of the substrate (soil/sand mixture) since we may obtain cuttings best survival (95-100\%). This substrate appears to be suitable for the conservation of Gnetum cuttings. Similar results were obtained using Gnetum (ICRAF, 2012).

The results indicate that the roots with yellow colour showed a good development of the mantle and Hartig net. After 8 weeks of cultivation, observations made with the naked eye showed that in crop field soil from Okola, Scleroderma colonize the roots of Gnetum sp to $66 \%$. These results are similar but faster than those obtained by Bechem et al. (2009) since a golden yellow colour was observed on the roots of Gnetum 6 weeks after inoculation and gained $68 \%$ colonisation after 16 weeks in bags in the greenhouse. The confirmation was made later that 8 weeks after inoculation, Gnetum-Scleroderma symbiosis is already well established with a good development of the mantle and Hartig net and inoculation is possible using spores Scleroderma sinnamariense (Bechem et al., 2009). This performance highlights the importance of a good balance between the crop field soil and aeration of the substrate for a better rooting of cuttings. It is therefore strongly advised to use as a rooting substrate a mixture of crop field soil and sand.

\section{Effect of beneficial microorganisms on} Gnetum mycorrhizal seedlings development

The results obtained show that Gnetum spp. roots are mainly colonize by ectomycorrhizal fungi (EMF), but the arbuscular mycorrhizal fungi (AMF) may do so also. Using a soil containing a mixture of selected strains of AMF only, we noticed that Gnetum roots was colonized by this inoculum by 40 $70 \%$ on sterilized and unsterilized soils. In the presence of only EM fungi, 20-30\% growth increase; for both AM fungi and EM fungi, we noticed a growth increase of $40 \%$; but using the sole AM fungi inoculum this increase as high as $50-55 \%$. This support the idea that Gnetum growth may be better in the presence of some beneficial microorganisms. Since Onguene (2000), Bechem et al. (2009) have not demonstrate the AM fungi status of Gnetum roots, we suggest to confirm the observation and importance of microbial consortia. 


\section{Conclusion}

The aim of this investigation is to have a better understanding of the role of soil microorganisms and Land Use Systems (LUS) on rooting of Gnetum cuttings. Chemical composition and texture of clayey-sandy soils may greatly influence Gnetum growth parameters. A good environment with adequate physico-chemical properties, rich in organic matter and soil beneficial microorganisms such as arbuscular mycorrhizal fungi, Scleroderma symbiotic to Gnetum are suitable for growing this special plant. Mastering Scleroderma propagation and selection will definitely contribute to Gnetum domestication and production. Sterilization strongly reduce soil fertility, kill beneficial microorganisms and cause poor plant growth. The results obtained show that not only EM fungi colonize Gnetum spp roots, but also AM fungi. A better Gnetum growth may be achieved in the presence of some symbiotic helper microorganisms including both AM and EM fungi. The originality of this work rely on the observation that a double arbuscular and ecto-mycorrhiza symbiotic association with Gnetum must be possible and confirmed. This is thought to be a major innovation for the domestication and production of theses endangered plant species.

\section{COMPETING INTERESTS}

The authors declare that they have no competing interests.

\section{AUTHORS' CONTRIBUTIONS}

This work was proposed and directed by ND for BCL masters who did the technical and writing aspects. AAM and MBA, took part respectively in examining the work and correcting this manuscript. The final lecture and overall verifications were made by ND who improved the quality and assured the scientific aspect of the work.

\section{ACKNOWLEDGEMENTS}

We are thankful to the Common Initiative Group AGRIBIOCAM (for the promotion of eco-farming), for providing infrastructures for plant growth, the Head of
Soil Microbiology Laboratory, and the Director of Biotechnology Centre, University of Yaoundé I for analysis. We also thank the anonymous reviewers for their suggestions and comments. Our gratitude goes to the $\mathrm{PAPCO} / \mathrm{MINADER}$ for the financial support.

\section{REFERENCES}

Ahoudi H, Gnandi K, Tanouayi G, OuroSama K, Yorke JC, Creppy EE, Moesch C. 2018. Assessment of pesticides residues contents in the vegetables cultivated in urban area of Lome (southern Togo) and their risks on public health and the environment, Togo. Int. J. Biol. Chem. Sci., 12(5): 2172-2185. http://ajol.info/index.php/ijbcs.

Bechem TE. 2011. Growth and in vitro phosphate solubilising ability of Scleroderma sinnamariense: A tropical mycorrhiza fungus isolated from Gnetum africanum ectomycorrhiza root tips. $J$. Yeast Fungal Res., 2 (9): 132 - 142. http://www.academicjournals.org/JYFR.

Bechem TE, Alexander IJ. 2009. Inoculum production and inoculation of Gnetum africanum rooted cuttings using a range of mycorrhizal fungi. Int. J. Biol. Chem. Sci., $\quad 3(3)$ : $\quad 578-586$. http://ajol.info/index.php/ijbcs.

Bechem TE, Alexander IJ. 2012. Phosphorus nutrition of ectomycorrhizal Gnetum africanum plantlets from Cameroon. Plant Soil, 353: 379-393. DOI: 10.1007/s11104-011-1038-x.

Biye E, Balkwill K, Cron G. 2013. A clarification of Gnetum L. (Gnetaceae) in Africa and the description of two new species. Plant Syst Evol, 300(2): 263272. DOI: http: //10.1007/s00606-0130879-6.

CITES. 2005. Strategic vision through 2005. CITES-UNEP. $48 \mathrm{p}$. DOI: http://www.cites.org

Dabré A, Hien E, Somé D, Drevon JJ. 2017. Effets d'amendements organiques et phosphatés sous zaï sur les propriétés chimiques et biologiques du sol et la 
qualité de la matière organique en zone soudano-sahélienne du Burkina Faso. Int. J. Biol. Chem. Sci., 11(1): 473-487. http://ajol.info/index.php/ijbcs.

FAO. 1976. Carte mondiale des sols à $1 /$ 5.000.000. vol. I : Légende, $62 \mathrm{p},+1$ carte h.t. (1975); vol. VI: Afrique, 307p. +3 cartes h.t. (1976) UNESCO, Paris.

FAO. 2003. Gestion de la fertilité des sols pour la sécurité alimentaire en Afrique subsaharienne, Rome, Italy, p. 63.

ICRAF. 2012. Le bouturage de Gnetum : ICRAF, Yaoundé, Cameroun. $2 \mathrm{p}$.

Iqbal MF, Maqbool U, Perveez I, Farooq M, Asi MR. 2009. Monitoring of insecticide residues in brinjal collected from the market of Noshera virkan, Pakistan. $J$. Anim. Plant Sci., 19: 90-93. DOI: http://www.researchgate.net/publication/ 265431600.

İsfendiyaroğlu M, Özeker E, Başer S. 2009. Rooting of 'Ayvalik' olive cuttings in different media. Span J Agric Res, 7(1): 165-172. DOI: $10.5424 /$ sjar/2009071408.

Kamgaing S. 2009. Rapport panorama I sur les statistiques agricoles et alimentaires au Cameroun. FAO: Rome, Italie; 78 p.

Kormanik PP, Mc Graw AC. 1982. Quantification of vesicular-arbuscular mycorrhizae in plant roots. In Methods and Principles of Mycorrhizal Research, Schenk NC (ed). APS Press: Minneapolis, USA.

Kutnjem D. 2008. Approches de la domestication de Gnetum africanum Welw (Gnetaceae) : production des plants. Mémoire de Maîtrise, Université de Yaoundé I, Yaoundé, p.50.

Leakey R, Mésen J, Tchoundjeu Z, Longman K, Dick J, Newton A, Matin A, Grace J, Munro R, Muthoka P. 1990. Lowtechnology techniques for the vegetative propagation of tropical trees. Commonw. For. Rev., 9(3): 247-257.
Ngo Nkot L, Nwaga D, Ngakou A, Fankem $\mathrm{H}$, Etoa F-X. 2011. Variation in nodulation and growth of groundnut (Arachis hypogaea L.) on oxisols from land use systems of the humid forest zones in southern Cameroon. Afr. J. Biotech., 10(20): 3996-4004.

Ngonkeu MEL, Nwaga D. 1998. Diversité des endomycorhizes de quelques sols du Cameroun, leur potentiel infectieux et réponse du mil et du niébé à l'inoculation. Biosciences Proceedings, 5: 186-198.

Nwaga D, Jansa J, Abossolo A. 2010. The potential of soil beneficial microorganisms for slash-and-burn agriculture in the humid forest zone of Sub Saharan Africa. In Soil Biology and Agriculture in the Tropics, Dion P (ed). Springer-Verlag: Berlin, Heidelberg; 81107.

Nwaga D, Mbarga Bindzi, Biye H, Atangana Eteme R, Ngonkeu MEL. 2003. Diversité des champignons mycorhiziens arbusculaires et biomasse microbienne des sols des zones de forêt humide du sud-Cameroun: effet des systèmes d'utilisation des terres. Ann. Fac. Sc. Univ. Yaoundé I, 35(2): 14-23.

Nwaga D, Ngonkeu MEL, Oyong MM, Ngakou A, Abelong M-P, Foko J. 2000. Soil beneficial micro-organisms and sustainable agricultural production in Cameroon: current research and perspectives. In: The biology and Fertility of Tropical Soils, TSBF Report 1998, UNESCO-TSBF, Nairobi, Kenya, pp. 62-65.

Onguene NA. 2000. Diversity and dynamics of mycorrhizal associations in tropical rain forests with different disturbance regimes in south Cameroon. PhD thesis, Wageningen University, Wageningen, $p$. 25.

Sanon KB, Bâ AM, Delaruelle C, Duponnois R, Martin F. 2009b. Morphological and molecular analysis in Scleroderma 
species associated with some Caesalpinioid legumes, Dipterocarpaceae and Phyllanthaceae trees in southern Burkina Faso. Mycorrhiza, 19: 571-584. DOI: http : 10.1007/s00572-009-0272-z. Sanon KB, Dianda MS, Guissou T, Bâ MA. 2009a. Description des champignons ectomycorrhiziens du genre Scleroderma de quelques formations forestières $\mathrm{du}$ Burkina Faso. C.A.J.E.B., 05 (02): 69 $78 . \quad$ http://www.ajol.info/browsejournals.php

Sieverding E. 1991. Vesicular-arbuscular mycorrhiza management, in tropical Agrosystems, GTZ n²24 Eschborn, Germany, p. 281.

Swift MJ, Bignell DE, Huang SP, Cares JE, Moreira F, Pereira EG, Nwaga D, Holt JA, Hauser S. 2001. Standard methods for assessment of soil biodiversity and land use practice. In: The ASA Review Meeting 1999, ASB Project, Bogor, Indonesia, ICRAF, Vol 1, 40 p.

UNCED. 1992. Agenda 21: Promoting sustainable agriculture and rural development. UNEP, Rio de Janeiro, Brazil.125-148p.

http://www.un.org/esa/sustdev/agenda21. htm.

Zeinabou H, Mahamane S, Bismarck NH, Bado BV, Lompo F, Bationo A. 2014. Effet de la combinaison des fumures organo-minérales et de la rotation niébémil sur la nutrition azotée et les rendements du mil au sahel. Int. J. Biol. Chem. Sci., 8(4): 1620-1632. http://ajol.info/index.php/ijbcs. 